\title{
Climate change and adaptation to social-ecological change: the case of indigenous people and culture-based fisheries in Sri Lanka
}

\author{
Eranga K. Galappaththi ${ }^{1}$ • James D. Ford ${ }^{2}$ • Elena M. Bennett ${ }^{3}$
}

Received: 25 June 2019 / Accepted: 6 April 2020/Published online: 27 April 2020

(C) Springer Nature B.V. 2020

\begin{abstract}
Rural coastal fishery systems in tropical island nations are undergoing rapid change. Using a case study from eastern Sri Lanka, this paper examines the ways in which indigenous CoastalVedda fishers experience and respond to such change. We conducted semi-structured interviews $(n=74)$, focus group discussions ( $n=17,98$ participants), and key informant interviews $(n=38)$ over a 2-year period (2016-2019). The changes that most Coastal-Vedda fishers experience are disturbance from Sri Lankan ethnic war, changes in climate and the frequency and severity of natural disasters, increased frequency of human-elephant conflicts, increasingly unpredictable weather patterns, and transformation of the Coastal-Vedda due to social modernisation. We used a resilience-based conceptual framework focusing on place, human agency, collective action and collaboration, institutions, indigenous and local knowledge systems, and learning to examine fishers' responses to rapid changes. We identified three community-level adaptive strategies used by the Coastal-Vedda: adaptive institutions with a multi-level institutional structure that facilitates collective action and collaboration, the use of culture-based fisheries (CBF), and diversification of livelihoods. We also recognized four place-specific attributes that shaped community adaptations: cultural identity and worldviews, co-management of CBF, flexibility in choosing adaptive options, and indigenous and local knowledge systems and learning. These adaptive strategies and place-specific attributes provide new insights for scientists, policymakers, and communities in the region, enabling them to more effectively work together to support community adaptation.
\end{abstract}

Keywords Adaptation - Coastal-Vedda Culture-based fisheries $\cdot$ Aquaculture $\cdot$ Climate change . Sri Lanka $\cdot$ Resilience

Electronic supplementary material The online version of this article (https://doi.org/10.1007/s10584-02002716-3) contains supplementary material, which is available to authorized users.

Eranga K. Galappaththi

eranga.research@gmail.com

Department of Geography, McGill University, Montreal, Canada

2 Priestley International Centre for Climate, University of Leeds, Leeds, UK

3 Department of Natural Resource Sciences, McGill University, Montreal, Canada 


\section{Introduction}

While environmental change is global, its effects are felt most directly by local communities. Rural Coastal-Vedda communities in Sri Lanka are undergoing complex changes including climate change impacts (e.g., frequent extreme weather events leading to floods and droughts) (Esham and Garforth 2013; Truelove et al. 2015), civil war (1983-2009) (Aaronson 2016; Zoysa 2018), tsunami devastation (2004) (Lehman 2014), and globalization. These changes have profound impacts on Coastal-Vedda communities, altering their livelihoods, culture, and lifestyle, and creating risks and opportunities (Pelling et al. 2015). Coastal-Vedda communities are also likely to be amongst those most exposed to and impacted by climate change. Identifying ways to reduce, through adaptation, the risks that global and local changes pose is an emerging topic in research on decision-making in natural resource management sectors including fisheries and aquaculture (Cinner et al. 2018; Galappaththi et al. 2019). Understanding how fisheries and aquaculture communities experience and respond to rapid change is essential for supporting adaptation processes.

While empirical assessment of communities' adaptation to change is an increasingly active area of research, little work focuses on indigenous peoples and culture-based fisheries (CBF), ${ }^{1}$ particularly climate change in eastern Sri Lanka. Studies do focus on other aspects of CBF (Amarasinghe and Nguyen 2009; Pushpalatha and Chandrasoma 2010; Amarasinghe and Wijenayake 2015; Wijenayake et al. 2016) and climate change impacts (Yamane 2003; De Silva et al. 2007; Esham and Garforth 2013) in Sri Lanka. The eastern part of the island has received limited attention due mainly to its three decades of civil unrest (Lehman 2014). Against this backdrop, we use a case study from the Kunjankalkulam community in eastern Sri Lanka to assess community adaptations to climate change in Coastal-Vedda fisher communities. The paper has two objectives: (i) examine how Coastal-Vedda fishers experience change, including climate change, and (ii) investigate how Coastal-Vedda fishers respond and adapt to such change. In the next section, we describe Coastal-Vedda within the context of the indigenous populations of Sri Lanka, and the study's conceptual and methodological approach. Following the 'Methods' section, we reveal means by which Coastal-Vedda fishers build resilience and minimise vulnerability (i.e., adapt) to the impacts of climate change. Finally, we identify potential community adaptive strategies and attributes that shape community adaptations in a CBF setting.

\section{Methods}

\subsection{Indigenous peoples in Sri Lanka}

Sri Lanka's indigenous populations refer to themselves as Wanniya-laeto ("people of the forest') (Lund 2000: 102). Most Sri Lankans use 'Vedda' ${ }^{3}$ to identify the country's indigenous populations (Seligmann and Seligmann 1911; Lund 2000; Attanapola and Lund 2013). This

\footnotetext{
${ }^{1} \mathrm{CBF}$ are essentially a form of extensive aquaculture, or a farming practice, conducted in small water bodies (generally less than 100 ha). These water bodies would not be able to support a capture fishery due to a lack of adequate natural recruitment of suitable species. Artificial water bodies, not built for fishery/aquaculture purposes (such as village tanks) but often built for irrigation purposes, can be used (De Silva et al. 2006: 11).

${ }^{2}$ Wanniya-laeto is the plural term and Wanniya-laeta (masculine) or Wanniya-laeti (feminine) is the singular term.

${ }^{3}$ Vedda is the singular term and Veddas is the plural.
} 
term means 'the person who uses bows and arrows', referring to their practices of shifting cultivation, hunting, and trapping and of collecting forest products (Dharmadasa 1993). The Wanniya-laeto have their own culture, way of life, and personality (Seligmann and Seligmann 1911). In determining geographical boundaries, they recognize only natural landmarks. They also protect the forest they inhabit, as they believe their ancestors' spirits belong to it (Lund 2000). However, from ancient times (including the war period), the Wanniya-laeto have peacefully co-existed with the island's majority Singhalese and Tamil populations (Seligmann and Seligmann 1911; Brow 1978; Dharmadasa 1993).

Throughout the nineteenth and twentieth centuries, the Wanniya-laeto were marginalized and forced to relocate (Lund 2000: 102) mainly because of (post) colonialism and development activities (Attanapola and Lund 2013). The Sri Lankan government is primarily responsible for marginalizing and disempowering the indigenous population, mainly by weakening the population's knowledge systems and capacities (Lund 2000; Attanapola and Lund 2013). Thus, the locals have lost their connection to ancestral lands (Lund 2000). The Wanniya-laeto have rapidly and inconsistently adapted to new social, cultural, and political contexts, including the new administrative structure and market economic system (Lund 2000; Attanapola and Lund 2013). They appear to be at a crossroads between traditional and modern systems (Latour 2012; Attanapola and Lund 2013).

In this paper, we study Coastal-Vedda, ${ }^{4}$ a group of Wanniya-laeto who migrated to eastern Sri Lanka's coastal areas. Historically, Coastal-Vedda moved within the forest in the eastern coastal belt, fishing and cultivating vegetables around their huts and in clearings in the jungle (slash, burn, and shifting to another area) _ known as 'Chena cultivation' (Dharmadasa 1993; Childs 2017). They cultivated maize, pumpkin, and other easy-to-grow crops. Later, CoastalVedda mixed with the Tamil populations in the eastern area. ${ }^{5}$ The main livelihood of the Coastal-Veddas living on the seaboard was fishing in the sea or in lagoons (Seligmann and Seligmann 1911; Dharmadasa 1993). The others fished in tanks, rivers, and streams, using methods, such as emptying water courses, and using poisonous leaves and creepers. They used traditional fishing gear like karaka and kemana, as well as made their own, such as cast nets, spears, and bifid iron spearheads. Coastal-Vedda also use arrows as harpoons for fishing (Seligmann and Seligmann 1911).

Currently, Coastal-Vedda live in four villages in the eastern region. They have lived in Kunjankalkulam since the 1960 s, after the government built the village tank to promote irrigation (rice farming). The national Coastal-Vedda chief resides in Kunjankalkulam (population $=193)($ Fig. 1). The Kunjankalkulam Wanniya-laeto population has indigenous cultural practices and values similar to inland Wanniya-laeto. Kunjankalkulam is a remote, isolated community accessible only by a gravel road. People use bicycles, motorbikes, and tractors to commute. The inhabitants face unique challenges including food insecurity, a lack of drinking water and infrastructure (roads and housing), and low high school graduation rates (Herath and Joseph 2016; Gunatilaka 2017). This region was affected by the Sri Lankan civil war (19832009), tsunami devastation (2004), and climate change impacts such as droughts, floods, and tropical storms (De Jong et al. 2002; Yamada et al. 2006; Esham and Garforth 2013), which increases the complexities of the Coastal-Vedda way of life and the natural environment.

\footnotetext{
${ }^{4}$ Coastal-Vedda refer to themselves as Muhudu-Vedda, meaning Wanniya-laeto of the coast. The term CoastalVedda is the standard translation of Muhudu-Vedda.

${ }^{5}$ Eastern Sri Lanka used to be a Tamil-dominated area but presently Muslim populations are becoming more dominant in terms of population growth and culture, including building architecture.
} 
Kunjankalkulam is one of the few Coastal-Vedda communities in the region with a high level of fishery activity and high non-fishery livelihood diversity. Coastal-Vedda use a village tank (reservoir) to raise fish (i.e., CBF) as a main community livelihood activity. The community is in a dry climatic zone where $\mathrm{CBF}$ is challenging. The north-eastern tropical monsoon and the weather dynamics in the Bay of Bengal influence the region's weather. Eastern Sri Lanka gets rain and high winds between October and January and remains dry for the remaining months (especially May through September). Rice farming is another essential livelihood activity, though unexpected climate changes (mainly extended droughts) do not allow Coastal-Vedda to farm consistently. Human-wild elephant conflicts are common; protecting the rice harvest from elephants is another challenge facing Coastal-Vedda. Furthermore, Coastal-Vedda use the surrounding forest for livelihood activities such as collecting wild honey, medicinal/edible plants, fruits, and wood for selling, as well as trapping/hunting.

\subsection{Conceptual approach}

We took a social-ecological systems (SES) approach to understand the interconnected but partly distinct nature of integrated Coastal-Vedda and Kunjankalkulam sub-systems (Berkes et al. 1998, 2003). The SES approach emphasizes neither purely ecosystems nor societies; rather, the SES and the connections between the system's ecological and social components are the focus. Economic systems and markets are not treated separately but as deeply nested in an SES approach, creating understanding of the complexities in Coastal-Vedda aquaculturewhat can be termed 'complex adaptive aquaculture systems' (Mahon et al. 2008; Folke 2016; Arlinghaus et al. 2017). 'Aquaculture systems' refers to the coupled sub-systems of Kunjankalkulam Coastal-Vedda and their forest/land/water and associated socio-economic and cultural aspects related to $\mathrm{CBF}$ activities.

We use a resilience-based conceptual framework (Galappaththi et al. 2019) to identify and assess the adaptations of Kunjankalkulam Coastal-Vedda towards stressors of the aquaculture system. The framework has six characteristics that develop an understanding of SES change and human responses to such change: place, human agency, collective action and collaboration, institutions, indigenous and local knowledge (ILK) systems, and learning (Table 1). This framework provides indicators that guide the assessment process. Results are structured around such indicators under each framework characteristic. A unique conceptualisation of resilience (as a function of coping, adapting, and transformative capacities) (Béné et al. 2014; Brown 2016) permits a macro-level understanding of adaptation with micro-level comprehensive

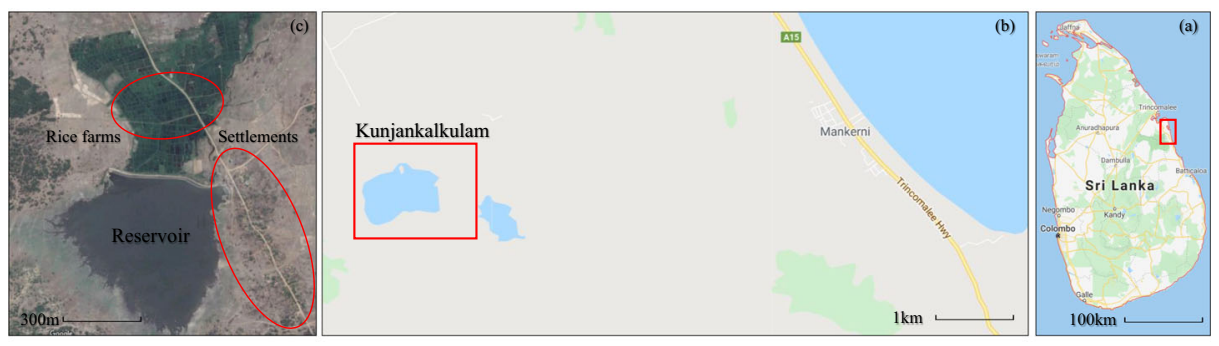

Fig. 1 Study location. a Eastern Sri Lanka, b Location of the Kunjankalkulam community, c Reservoir, village settlements, and rice farms 
details in fishing communities. This conceptual tool was developed through an integration of resilience thinking and development studies (Galappaththi et al. 2019). We used this framework to assess the community adaptation process in Coastal-Vedda aquaculture systems and obtain insights into adaptation needs and relevant policy.

Table 1 Definitions of characteristics of the resilience-based framework (Galappaththi et al. 2019)

\begin{tabular}{|c|c|}
\hline Characteristic & Definition \\
\hline Place & $\begin{array}{l}\text { Social and physical space with attachments } \\
\text { to Coastal-Vedda and social processes. } \\
\text { Attachment to place is understood as } \\
\text { bonding that occurs between people and } \\
\text { their meaningful environments (e.g., } \\
\text { livelihoods, culture, and well-being). }\end{array}$ \\
\hline Human agency & $\begin{array}{l}\text { Coastal-Vedda (individual or collective) } \\
\text { capacity to act independently in making } \\
\text { decisions as part of the Coastal-Vedda } \\
\text { way of life. }\end{array}$ \\
\hline $\begin{array}{l}\text { Collective action and } \\
\text { collaboration }\end{array}$ & $\begin{array}{l}\text { Action taken together (or shared) by a } \\
\text { group of two or more people to meet a } \\
\text { common desired objective. }\end{array}$ \\
\hline
\end{tabular}

Indicators

(1) Number of species available for fishing.

(2) Level of fishery/aquaculture resource availability.

(3) Level of vulnerabilities for fishing operations such as climatic uncertainties.

(4) Changes in livelihood activities relative to place (hunting/fishing).

(5) Culture, including belief systems and perceptions linked to place.

(1) Ownership of or access to fishing gear (canoes, nets).

(2) Fishing gear diversity (number of different items of fishing gear used).

(3) Occupational mobility (number of different fishing operations practiced).

(4) Occupational multiplicity (number of jobs in the household).

(5) Access to credit (loans) and insurance.

(6) Use of technological advancements.

(1) Sharing of fish.

(2) Sharing of fishing gear.

(3) Spreading of weather information.

(4) Sharing of information about fishing operations (selling prices, production quotas, and techniques/management practices).

(5) Social networks.

Institutions Local organizations that facilitate collective

(1) The aim of institutions (e.g., action meeting a local goal (e.g., co-managed institutions). contribution to local aquaculture activities).

(2) Ownership (communal, local/indigenous, private).

(3) Decision-making power.

(4) Existence of partnerships.

ILK systems

Co-evolving cumulative body of knowledge (including observations, experience, lessons, and skills) belonging to Coastal-Vedda aquaculture systems (or a place) and handed down through generations by cultural transmission; reflects Coastal-Vedda cultural identity.

Learning

Social learning, which itself is collective action and reflection among Coastal-Vedda as they work to improve the management of human-environment interactions.

(1) Application of such knowledge.

(2) Co-production of knowledge (combining indigenous knowledge with other kinds of knowledge such as local knowledge and/or traditional knowledge).

(3) Weakening of local/indigenous/ traditional knowledge throughout SES change.

(1) Extent of the practice of learning-by-doing in the fishing way of life.

(2) Number of learning opportunities.

(3) Ways local philosophical worldviews are compatible with adaptive thinking. 


\subsection{Data collection methods}

We used a community-based participatory research approach (Magee 2013) to ensure community engagement in shaping knowledge production. The study received community feedback through the national Coastal-Vedda chief, informants from local institutions (e.g., NAqDA - National Aquaculture Development Authority, Batticaloa), and research assistants. During field data collection, the researcher relied on five language translators (Tamil/CoastalVedda language to English) and three local research assistants. All field data were collected according to the McGill Research Ethics Board Certificate of Ethical Acceptability of Research Involving Humans (file number 52-0617) as well as under the consensus of the (Coastal) Vedda chief of Sri Lanka.

We used a qualitative research design for primary data collection to understand how Coastal-Vedda fishers experience and respond to SES change, including climate change, in Kunjankalkulam. Field data were collected using multiple methods: participant observations (PO), semi-structured interviews (SSI), key informant interviews (KII), and focus group discussions (FGD) (Berg 2016; Laurier 2016; Longhurst 2016). PO helped us obtain contextual knowledge about Coastal-Vedda experiences and responses to change. As of March 2019, we had conducted 24 weeks of in-field PO during three visits to Kunjankalkulam and the surrounding area. The first visit was in August 2016 and involved reconnaissance, preliminary data collection, and the gathering of community feedback. The second visit was from September to December 2017 and involved the collection of data about the Coastal-Vedda's CBF and how locals cope with the rainy season. The third visit was from April to July 2018 and involved the collection of data about the changes Coastal-Vedda face during the dry season and their adaptations. The researcher's daily-updated field diary helped track PO data. The researcher spent much time with Coastal-Vedda fishers, attending community events, meetings, and community-based institutions. The researcher also made $>20$ fishing trips to the village reservoir and participated in most activities (e.g., fish stocking, net setting, harvesting, and fish landing site activities).

Seventy-four face-to-face semi-structured interviews (SSI) (Longhurst 2016) were conducted with Coastal-Vedda fishers to document changes in the region and identify/characterize the response to them (Appendix-Table S1-key themes of the interview guide). A snowball sampling technique was used to select participants (3). Initially, the Coastal-Vedda leader introduced the researcher to the community; the researcher made most appointments via cell phones and sometimes by walking in. We recruited participants until saturation, when interviewees provided no new relevant information (Bowen 2008). These interviews were conducted, audiorecorded, and transcribed in Kunjankalkulam from September 2017 through July 2018 (Appendix-Table S2-sample profiles). The SSI questioning focused on 'change' in general to prevent bias and to keep the interviews open-ended, focusing on the issues and changes that Coastal-Vedda viewed as most important. This sample consisted of Coastal-Vedda fishers who permanently live in Kunjankalkulam. SSI obtained richer insights into 'place' and its meanings/ attachments (Williams and Patterson 2008; Kaján 2014). All the interview questions relating to 'change' referred to 'about 30 years back' in Coastal-Vedda's lives.

Thirty-eight key informant interviews (KIIs) were conducted and included questions about Coastal-Vedda, climate change, and CBF. The goal was to examine topics not accessible via PO and SSI, such as the Coastal-Vedda population (national indigenous chief and Ministry of Cultural Affairs to find/verify the Coastal-Vedda community), co-management of CBF (e.g., NAqDA), and adaptive responses (e.g., NGOs-non-governmental organizations) in the 
community. The researcher conducted interviews with representatives from NAqDA $(n=4)$, the Ministry of Cultural Affairs $(n=4)$, the Department of Fisheries-Batticaloa $(n=2)$, the Divisional Secretariat Office-Vakarai $(n=1)$, the Ministry of Mahaweli Development and Environment-Colombo $(n=6)$, the Department of Meteorology-Batticaloa $(n=1)$, the World Vision International Zonal Office-Vakarai $(n=1)$, the Sabaragamuwa University of Sri Lanka $(n=1)$, and the University of the Visual and Performing Arts-Colombo $(n=1)$, as well as individuals with knowledge of Coastal-Vedda $(n=17)$. KII helped validate and describe data gathered using other methods.

Seventeen focus group discussions (FGD) (Carey and Asbury 2016) were undertaken with 98 respondents to build thematic areas related to changes that Coastal-Vedda fishers experience (e.g., climate extremes, unpredictable weather patterns, increased human-elephant conflicts during the post-war period) and to identify how Coastal-Vedda respond to such changes (e.g., collective action and collaborations, community-based institutions, knowledge systems, and aquaculture). Coastal-Vedda groups of four to eight individuals participated in the FGD, organized throughout the data collection process (Appendix-Table S3-Details of FGDs). Furthermore, FGD validated the data collected using other methods.

\subsection{Data analysis}

Qualitative interview data were translated into English and transcribed, then analysed using content analysis (Yow 2014; Hancock and Algozzine 2015; Berg 2016; Clifford et al. 2016). The key techniques were manifested and latent content analysis (Vaismoradi et al. 2016; Krippendorff 2018) supplemented with critical discourse analysis (Van Dijk 2015; Wodak and Meyer 2015) to develop themes and patterns related to Coastal-Vedda's experience and response to change. We also used direct quotations to support the results. We used Microsoft Excel 2013 to create descriptive statistics (e.g., percentages, mean values, standard deviations). Percentages in the text refer to the number of respondents from the immediately mentioned sub-sample who made that statement. Initially, the study recorded 16 types of changes that Coastal-Vedda fishers experienced. We selected the five most-recorded areas of change (based on the data frequency) for further analysis. The results were supplemented with selected quotes (from SSI/KII) based on the latent content analysis. We identified links among the selected changes using data from PO and SSI and validated them through KII and FGD. Data relating to Coastal-Vedda fishers' response to change were mostly fed through the PO data (research diary, photos, and the researcher's first-hand experience), supplemented with SSI and KII.

\section{Results}

\subsection{Experiencing SES change}

Coastal-Vedda experience change in many ways. Key changes are continued disturbances resulting from the civil war, extreme weather and natural disasters (e.g., cyclones, floods, drought), increased human-elephant conflicts, increasingly unpredictable weather patterns, social pressure from transformations towards modernization, materialistic values, and wellbeing. Some changes (e.g., human-elephant conflicts (Fernando et al. 2005; Santiapillai et al. 2010)) are more widely documented than others, yet certain changes are described as more important than others. These are profiled in Table 2. 
Table 2 Fishers' quotes describing how Coastal-Vedda experience change $(n=74)$

Nature of change: 'selected quotes from Impacts
fishers'

Continued disturbances to Coastal-Vedda way of life during the ethnic war (1983-2009) (86\%):

'...we [Coastal-Vedda] used to have more animals such as cattle, goats, chicken... but during the war we lost most of them [animals]...organised groups of people stole our village during fights...once we were back...our valuables are gone... including our animals.'

'...before war...we [Coastal-Vedda] had traditional hunting equipment [bow and arrow, spear] but during the war we got weapons...it was easy to hunt but after war we are not allow[ed] to keep guns anymore... and now we almost lost our traditional way of hunting.'

Extreme climate and natural disasters including cyclones, floods, and droughts $(64 \%)$ :

'...fishing is not safe when the tank floods...women do not fish in floods...'

'...we [Coastal-Vedda] can grow larger fish if we have more water [in reservoir] in dry season... [fish buyers] do not pay much for smaller fish...'

'...during dry season....cannot find water even for drinking.'

'... our [Coastal-Vedda] road completely eroded after heavy rains.'

Increasing in human-elephant conflicts during the post-war period $(57 \%)$ :

'...wild elephants are scared of shell sounds...but after war...they return to this [village]...they destroyed our house.'

'...electric fence around the village to protect us [Coastal-Vedda] from wild elephants is not working for long time [over 15 years]...'

An increase in unpredictable weather patterns $(30 \%)$ :

'...we cannot predict weather anymore... it's raining when it supposed to [be] sunny and it's drying when it supposed to rain.'

'last three years we [Coastal-Vedda] did not receive monsoon rain as we expected...we lost our rice crop...same with fish fingerling stocking.'

Coastal-Vedda transformation due to social modernization (Latour 2012), development of materialistic values, and wellbeing (Singh 2009)(28\%):
Coastal-Vedda lost livelihoods, lives, and assets during the war, disrupting the traditional way of life (hunting, cattle, chena cultivation) and weakening Coastal-Vedda's ILK systems. Now Coastal-Vedda cannot return to their old ways in terms of culture, education, and livelihoods.

Shorter favorable climate for CBF (fish stocking) and fishing activities because of drought, floods, and stormy conditions. Unfavorable conditions diminish fish growth (lack of water) and lessen fishing time (floods).

The wild elephant threat creates an unsafe environment in the village and limits nighttime fishing hours.

Unpredictable weather decreases Coastal-Vedda's ability to prepare for fishing and other livelihood activities; it also complicates Coastal-Vedda's way of life.

-Loss of livelihoods.

-Unsafe and high-risk living conditions.

-New lifestyle and social transformation.

-Shorter aquaculture season.

-Fewer fishing days/hours.

-Unsafe and high-risk living conditions.
-Fewer fishing days/hours.

-Unsafe and high-risk living conditions.
Coastal-Vedda's culture and value system are influenced by popular culture and the social modernisation process. Coastal-Vedda moved to new cement
-Shorter aquaculture season.

-Fewer fishing days/hours.

-Unsafe and high-risk living conditions.

-Loss of livelihoods. 
Table 2 (continued)

\begin{tabular}{|c|c|c|}
\hline $\begin{array}{l}\text { Nature of change: 'selected quotes from } \\
\text { fishers' }\end{array}$ & Impacts & Implications \\
\hline $\begin{array}{l}\text { '... World Vision [NGO] help[ed] us build } \\
\text { new cement house...' } \\
\text { '...they [NGO] gave us [fishing] nets and } \\
\text { fiberglass canoes...' } \\
\text { '...gentlemen from NGO teach us how to } \\
\text { save money...' } \\
\text { '...I [young Coastal-Vedda fisher] want to } \\
\text { [live] like other people in town...' }\end{array}$ & $\begin{array}{l}\text { housing funded by post-war/tsunami } \\
\text { development programs and began to } \\
\text { adapt to the cash economy and } \mathrm{CBF} /- \\
\text { aquaculture. They are shifting to a } \\
\text { materialistic-centered value system. }\end{array}$ & \\
\hline
\end{tabular}

\subsection{Responding to SES change}

This section examines how Coastal-Vedda respond to identified changes using the resiliencebased conceptual framework. It is structured around the themes of place, human agency, collective action, institutions, knowledge systems, and learning (Galappaththi et al. 2019).

\subsubsection{Place}

Place-specific conditions such as water availability for aquaculture, climatic conditions, and wildlife threats to livelihood activities can influence community adaptive capacity and processes (Amundsen 2015; Adger 2016). CBF supplies food for Kunjankalkulam year-round and is a key source of protein. This minor-non-perennial ${ }^{6}$ reservoir (110 ha) was built during the 1960s to meet the demand for water to cultivate rice but currently is used primarily for CBF activities. This reservoir can no longer accommodate the seasonal water demand for rice farming due to extended droughts. The reservoir is close to village housing and rice farms. With the support of the government, fisheries and aquaculture institutions, and NGOs, an annual stock of eight varieties of fish fingerlings (Appendix-Table S4-aquaculture species) grows in the natural reservoir system. In 2017, this reservoir was stocked with 250-300 k fish fingerlings (tilapia, carp, and indigenous fish) and 100-150 k freshwater prawn post-larvae. The estimated harvest for the year was 5-7 k MT fish and prawns. The peak season for fish harvesting is March-September; the offseason begins with the heavy rains in October. In 2018, this reservoir received a pen culture system stocked with $100 \mathrm{k}$ fish fingerlings.

Coastal-Vedda practice two types of fishing activities. During the day, fisherwomen enter the water to fish using rods (Appendix-Fig. S1-photos). They fish mainly for subsistence purposes. These locations change based on the reservoir water levels, which themselves depend on weather conditions. The most commonly caught fish are tilapia and indigenous fish. During the day, fishermen rest or engage in other livelihood activities. Fishermen go fishing in the early morning (2-3 am) in deep areas of the reservoir, using canoes and gill nets. They look for commercial species (e.g., freshwater prawns, well-grown carp, and tilapia). They use some of the harvest (small fish) for food purposes while selling large, high-quality fish to fish collectors (i.e., middlepersons who collect fish every morning and supply it to large markets in urban areas).

\footnotetext{
${ }^{6}$ Most of the reservoirs used for $\mathrm{CBF}$ /aquaculture are minor-non-perennial reservoirs (50-200 ha at full water supply level) in Sri Lanka.
} 
The Coastal-Vedda fishery system has place-specific vulnerabilities. Wild elephant attacks affect the community's fishing activities and peak during rainy seasons. To repel elephants, fishers use special firecrackers and create fires. The community also has an inoperable electrified fence. The need to spend time and energy on wild elephants affects nighttime commercial fishing activities.

\subsubsection{Human agency}

A high level of human agency can indicate a high adaptive capacity to change (Cinner et al. 2015; Galappaththi et al. 2019). This section uses livelihood diversification, access to credit, occupational multiplicity, access to assets, fishing gear diversity, and occupational mobility to understand the adaptive capacities of Coastal-Vedda fishers (Table 3).

Coastal-Vedda fishers engage in many livelihood activities to increase their income options in adverse conditions (Fig. 2). Some activities were historically practiced (collecting wild honey/fruits/wood, hunting/trapping, chena/rice cultivation), while others are recent additions (aquaculture, beach seine fishing, selling wild honey/fruits/wood, income support). These activities reduce Coastal-Vedda reliance on CBF (or one specific livelihood activity) for food security. Livelihood diversification decreases the opportunity cost of Coastal-Vedda's dependence on CBF for food. Almost all (100\%) the respondents were involved in CBF; 62\% engaged in fishing for commercial aquaculture and $38 \%$ were involved in subsistence aquaculture. Almost all fishers involved in subsistence aquaculture were female. Gender roles are clearly set among Coastal-Vedda; women are not directly involved in commercial activities including nighttime $\mathrm{CBF}$.

Table 3 Indicators of human agency $(n=74)$

\begin{tabular}{|c|c|c|c|c|}
\hline Indicators & Description & Mean & $\begin{array}{l}\text { Standard } \\
\text { deviation }\end{array}$ & How to improve adaptive capacity? \\
\hline $\begin{array}{l}\text { Occupational } \\
\text { multiplicity }\end{array}$ & $\begin{array}{l}\text { Total number of livelihood } \\
\text { activities practiced in the } \\
\text { household. }\end{array}$ & 3.8 & 1.3 & $\begin{array}{l}\text { Increase the range of income } \\
\text { options to cope with adverse } \\
\text { conditions. }\end{array}$ \\
\hline Access to assets & $\begin{array}{l}\text { Access to number of assets required } \\
\text { for fishing operations. We } \\
\text { studied four assets: canoe, cycle, } \\
\text { pen structure, and fishing gear. } \\
\text { The pen structure belongs to the } \\
\text { community aquaculture } \\
\text { institution (RFO). }\end{array}$ & 2.3 & 0.9 & $\begin{array}{l}\text { Increase people's ability to engage } \\
\text { in fishing activities; this allows } \\
\text { Coastal-Vedda to earn more } \\
\text { money and obtain enough food } \\
\text { to survive. }\end{array}$ \\
\hline $\begin{array}{c}\text { Fishing gear } \\
\text { diversity }\end{array}$ & $\begin{array}{l}\text { Number of types of fishing gear } \\
\text { used by each fisher. We studied } \\
\text { five types of fishing gear: gill } \\
\text { net, thread net, led net, fishing } \\
\text { rod, and pen structure. }\end{array}$ & 3.2 & 1.8 & $\begin{array}{l}\text { Increase the potential/capacity to } \\
\text { harvest a range of large fish/- } \\
\text { prawns, which results in a higher } \\
\text { income. }\end{array}$ \\
\hline $\begin{array}{c}\text { Occupational } \\
\text { mobility }\end{array}$ & $\begin{array}{l}\text { Number of fishing operations } \\
\text { practiced during the past year per } \\
\text { fisher. We studied four fishing } \\
\text { activities: reservoir fishing } \\
\text { (commercial), reservoir fishing } \\
\text { (subsistence), pen culture, and } \\
\text { beach seine fishing. }\end{array}$ & 2.1 & 0.4 & $\begin{array}{l}\text { Increase earning potential as well as } \\
\text { the fish harvest (for food), which } \\
\text { improves food availability and } \\
\text { buying power. }\end{array}$ \\
\hline
\end{tabular}




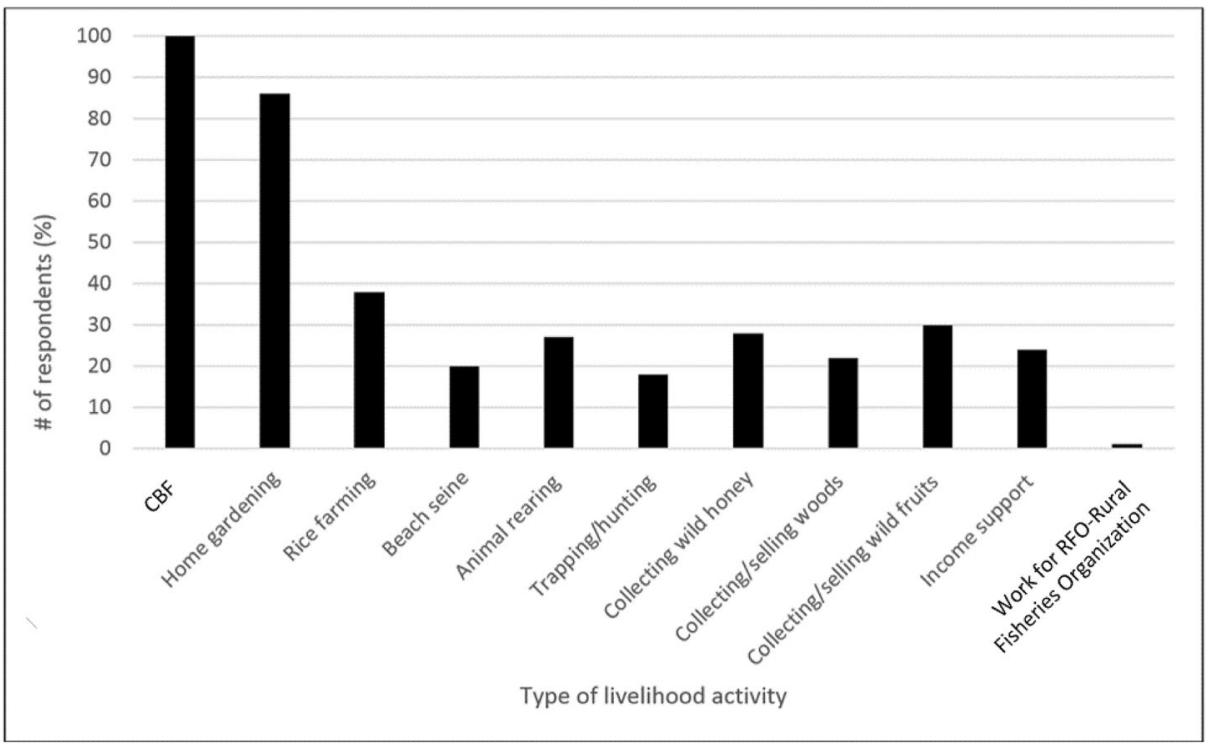

Fig. 2 Type of livelihood activities of Coastal-Vedda

... now we [Coastal-Vedda] save money, and women even have saving clubs ... learnt that [saving money] from an NGO program ... - Young Coastal-Vedda

It's hard during dry season and flood season, but we do multiple activities [livelihoods] ... I go fishing early morning and garden during the daytime ... sometimes going to forest [to collect honey, fruits, or wood] instead [of gardening] ... sometimes we buy rice or meat from town and make a vegetable and fish curry ... I have options [livelihoods] now and I don't need to miss any meals anymore...-Elder Coastal-Vedda

We observed limited or no modern or advanced technology in CBF operations among CoastalVedda. However, particularly after the war, Coastal-Vedda have been undergoing rapid social modernisation (Latour 2012), including the use of money (cash economy), modern clothing, cement housing, a non-mobile lifestyle, cell phone use, aquaculture, and fish selling activities (Childs 2017; Ranasinghe and Cheng 2018). Coastal-Vedda have limited access to credit (personal loans) for CBF activities but can borrow money from informal money lenders. Coastal-Vedda's CBF operation does not involve major expenses, with the exception of fish fingerling stocking, which is funded by RFO, NGOs, and the government. Furthermore, through fisher compensation programs, Coastal-Vedda can obtain low-cost canoes and fishing gear.

\subsubsection{Collective action and collaboration}

Collective action and collaboration shape community adaptation by improving community cohesion and unity, which helps members cope with common changes through enhanced collective adaptive capacity (Adger 2003; Armitage 2005; Pelling et al. 2008). Collective action is embedded in Coastal-Vedda's way of life. An example is fisherwomen's daytime subsistence fishing operation. All the fish are collected into one sack and distributed equally among the families. This fishing operation is led by the village first lady (spouse of the 
Coastal-Vedda chief). A rotational system determines who fishes on a particular day (similar to the Padu system (Lobe and Berkes 2004) but in this case, the catch is shared). The fishing time can vary from 2 to 5 hours depending on the fishing spot and the community's needs. Fisherwomen usually remain in one fishing area for at least 5 days. This routine changes due to weather, the need to engage in other livelihood activities, or cultural priorities.

Also, groups of two to four Coastal-Vedda fishermen gather at night for commercial fishing operations; they set their nets and share their income. A majority (over 90\%) of fishermen said they do not share large fish (of marketable size); however, they share small fish for food purposes. Most fishermen (52\%) will not share their fishing gear (gillnets, canoe). Only 15\% of fishermen said they would share. Within the sample of fisherwomen, 64\% said they would share their gear (fishing rods), while $25 \%$ said they would not.

Coastal-Vedda use informal social networks to share important information about CBF activities. People - especially women - gather around the water well and drinking water tank to share daily updates, including fisheries-related information (e.g., the quality of the fish harvest, who went fishing/is planning to fish, and changes in fish prices) and non-fisheriesrelated information (e.g., alerts about wild animals). People also use informal social networks to share information about extreme weather events. Most (89\%) fishermen have cell phones. Among fisherwomen, $46 \%$ use cell phones for communication. Informal social networks allow Coastal-Vedda to spread information more quickly than formal methods of information sharing (e.g., monthly fisheries cooperative meetings). Such information can be less precise but useful for a small society that does not rely on the internet.

\subsubsection{Institutions}

Local institutions can boost a community's adaptive capacity by engaging with fishery resource management approaches and collaborating with stakeholder institutions to minimize vulnerabilities in the use of natural resources. Kunjankalkulam's CBF is co-managed by a multi-level institutional structure with diverse stakeholder organizations that manage stress and change by sharing knowledge, identifying barriers, and learning from each other (Fig. 3). RFO (Rural Fisheries Organization) is the key fishery institution managing community-level CBF. It has annually appointed officers: a (vice) president, a secretary, and a treasurer appointed by RFO members (i.e., Coastal-Vedda fishers). The treasurer has the only paid full-time job. He must visit the landing site twice daily and record the number of canoes that entered the reservoir as well as how many fish was brought to the landing site (landing site management). Every commercial fisher must pay a fee to RFO based on their catch. Occasionally, RFO buys all the fish from the fishers and sells it back to the local market/vendors, depending on prevailing market prices. Currently, Kunjankalkulam RFO is one of 22 RFOs in the region (eastern fisheries division).

The Inland Fisheries Federation (IFF) is the regional-level aquaculture industry organization. IFF has significant control over the inland fish market price. The organization consists of leaders from 22 RFOs (e.g., the president). IFF charges RFOs a membership fee based on the reservoir size (Sri Lankan Rupee equivalent to C\$23 for minor, C\$38 for medium, and C\$76 for major). IFF also has annually appointed leadership positions: (vice) president, secretary, and treasurer. The president is part of the National Fisheries Federation (NFF), which oversees national-level fisheries and aquaculture concerns.

The Batticaloa regional center of the National Aquaculture Development Authority of Sri Lanka (NAqDA) directly supports the community adaptation process through co-management 


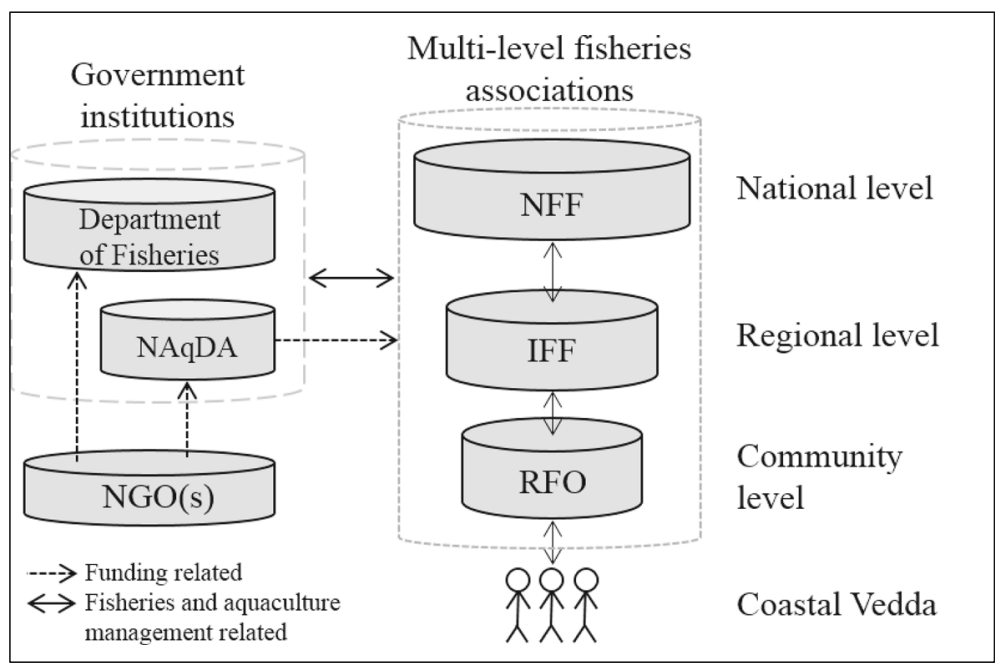

Fig. 3 Multi-level institutional structure for CBF co-management

of CBF. NAqDA is the national-level government institution for inland fisheries and aquaculture management. Extension officers of NAqDA work closely with RFOs to ensure that fishers follow regulations and procedures. The extension officers attend most RFO meetings and offer administrative support. For example, fishers must meet three key requirements to become involved in commercial CBF: (a) obtain an 'operating licence' from NAqDA (with no fees) for recording purposes so that NAqDA will know who the full-time fishers are (those who fish three or more times per week), (b) register their canoe (number) with the Department of Fisheries, Batticaloa, and (c) obtain fisher insurance (C\$8/year) from Ceylinco General Insurance Limited to mitigate fishers' health-related risks such as hospital bills and death during fishing-related activities.

NGOs play a key role in funding the CBF co-management process. The fish fingerling stocking process is partly funded through various NGOs (e.g., World Vision, FAO, Care, and USAID) and the government. RFO also contributes. For example, in 2018, Coastal-Vedda started an experimental pen culture project in the reservoir to increase the community's annual fish production. Furthermore, in 2017, Kunjankalkulam RFO received fishing gear and canoes as NGO donations. Additionally, Coastal-Vedda use many non-fisheries/aquaculture-related community-based institutions to cope with common challenges (Appendix box S1). Each institution is led by different Coastal-Vedda, which allows for collective leadership at the community level, improving the community's adaptive capacity.

Figure 3 shows the multi-level institutional structure of vertically integrated fishery associations and government and non-governmental organizations (NGOs). Multi-level fishery associations are horizontally integrated with government institutions primarily for fisheries and aquaculture management-related aspects (solid-line arrows) and with NGOs for specific project financing aspects (dotted-line arrows). RFO is the key community institution representing Coastal-Vedda with respect to $\mathrm{CBF}$.

Now village reservoir is our main way of living ... we are planning to further increase our fish production with the help of NAqDA and ... local NGOs ... I am glad they [NAqDA] help and consult us with technical expertise ... Today ... [...] NGO donate 
five canoes and gillnets for our fishers, they [NGO] have being helping us over the last year...-Coastal-Vedda chief

\subsubsection{ILK systems}

ILK systems are a source of resilience and a means of measuring the understanding of adaptations in a fisheries and aquaculture setting (Folke et al. 2003; Galappaththi et al. 2018, 2019). This section describes Coastal-Vedda applications of ILK, the combining of different types of knowledge, and the weakening of ILK systems throughout SES change.

Coastal-Vedda use various types of knowledge to cope with SES change. Table S5 in the appendix illustrates selected types of knowledge that Coastal-Vedda fishers use. We have identified various knowledge systems surrounding fishing spots, CBF operation, weather predictions, collective action, and climate adaptation responses. Furthermore, we have recognized essential knowledge for surviving in the 'place', such as knowledge about wild elephants and disaster/emergency practices. All acknowledged types of knowledge are currently practiced by Coastal-Vedda fishers and have been developed over the past three decades. Specific types of knowledge developed due to Coastal-Vedda's exposure to long-term stresses such as climate change impacts (adaptation knowledge) and war conditions (knowledge about disaster or emergency situations). Another sub-set of knowledge (weather predictions) has been used and is evolving.

Moreover, Coastal-Vedda believe that aspects of their ILK system are weakening, partly due to ethnic conflict and social modernization. Coastal-Vedda still possess specific knowledge that they have gained over the generations but do not often practice it. For example, a lack of traditional fishing and hunting activities results in weakened knowledge about making/ using traditional weapons (e.g., bow and arrow, spear). However, new knowledge about aquaculture can mitigate the livelihood impacts of weakened knowledge, enhancing CoastalVedda's capacity to adapt to SES change.

Now everything [has] changed. It is hard to predict weather, animals, even forest ... but we need to live. The government and NGOs [are] giving us new knowledge that help to develop aquaculture-Elder Coastal-Vedda

\subsubsection{Learning}

Learning is a key characteristic of community adaptation (Galappaththi et al. 2019). This section describes how Coastal-Vedda practice learning-by-doing in their fishing way of life, the available learning opportunities, and the ways Coastal-Vedda co-learning supports the local adaptation process.

Coastal-Vedda have various opportunities to learn and adapt to change (AppendixTable S6). Identified learning opportunities are learning-by-doing (65\%), local institutions such as RFO (53\%), external stakeholders such as NGOs (32\%), and parents and elders (28\%). In FGDs, all respondents agreed that by combining all learning opportunities, Coastal-Vedda co-learn in the context of CBF. 'Learning-by-doing' is a common application across multiple learning opportunities (e.g., RFO and NGO settings). Collective action and collaboration are key mechanisms for co-learning. Local institutions and community-based organizations 
facilitate Coastal-Vedda's co-learning process. Co-learning could lead to new knowledge such as aquaculture technology (e.g., pen culture to increase fish production).

Coastal-Vedda have access to formal education through a public school system. CoastalVedda children attend the nearest primary school (up to grade three) in nearby communities. Over the last three decades, ethnic conflicts have disturbed Coastal-Vedda education. Because they live in a geographically isolated rural fishing community, Coastal-Vedda fishers concentrate on identified opportunities for learning.

This effort [the co-management of $\mathrm{CBF}$ ] is teamwork, we tried many aquaculture activities over the last years ...we need patience ... and especially learning from our past mistakes is important to strongly face this change-Elder Coastal-Vedda

\section{Discussion}

We assessed Coastal-Vedda community adaptation by examining how Coastal-Vedda experience and respond to change in a small-scale aquaculture context (i.e., CBF). We illustrated five key stressors and shocks: the Sri Lankan ethnic war; extreme weather and natural disasters including cyclones, floods, and droughts; human-elephant conflicts; an increase in unpredictable weather patterns; and social pressure from modernization (Latour 2012). Compared to other small-scale fishery systems (Arimi 2014; Paprocki and Cons 2014; Khan et al. 2018), Coastal-Vedda have experienced a unique combination of changes over the last three decades. We discovered four characteristics of how Coastal-Vedda fishers experience change: (i) Coastal-Vedda's culture-based fisheries systems are undergoing multiple stressors, indicating that change is non-linear; (ii) climate change is perceived as one of many changes with mixed/ interconnected implications for Coastal-Vedda fisheries; (iii) Coastal-Vedda themselves (culture, economy, lifestyle) are transforming within the SES change over time; and (iv) responding to identified changes over a long period has made Coastal-Vedda more resilient to SES change.

Table 4 illustrates the implications of specific changes that Coastal-Vedda fishers experience, their potential outcomes, and community responses to them. Furthermore, Table 4 describes the conceptual link between the listed implication of change and the respective community responses. To advance the understanding of adaptive responses, we must investigate how Coastal-Vedda address the implications of changes differently from other documented small-scale fishery systems. An aquaculture-centered livelihood equipped with multi-level mixed governance institutions is the collective strategy that fosters community adaptation.

We identified three key adaptive strategies of Kunjankalkulam Coastal-Vedda that construct the community responses to SES change. First, we recognized CBF (or aquaculture) itself as an adaptation strategy. Coastal-Vedda once had wild capture fisheries and engaged in chena cultivation and rice farming; now, they are involved primarily in CBF (De Silva et al. 2006; Amarasinghe and Nguyen 2009). This aquaculture is the best fit for the changes surrounding Coastal-Vedda's SES, such as climate (e.g., cyclones, floods, and droughts) and way of life (e.g., non-mobile lifestyle). CBF can build more resilience among Coastal-Vedda than can other livelihoods, as it (i) reduces food insecurity by supplying consistent protein sources (Amarasinghe and Nguyen 2009), (ii) does not involve major investments (compared to intensive large-scale aquaculture operations), with the cost of fingerling stocking borne by 


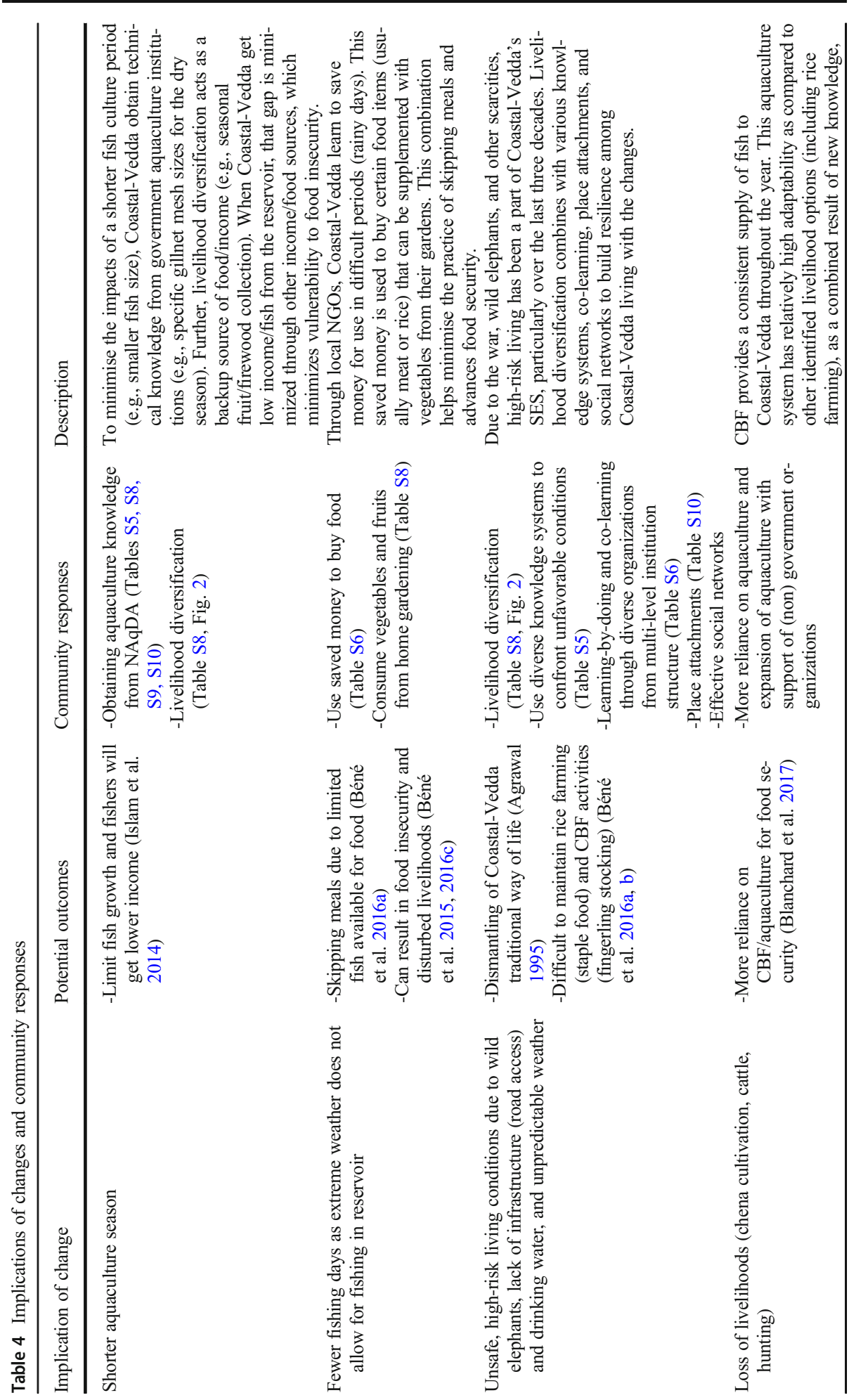




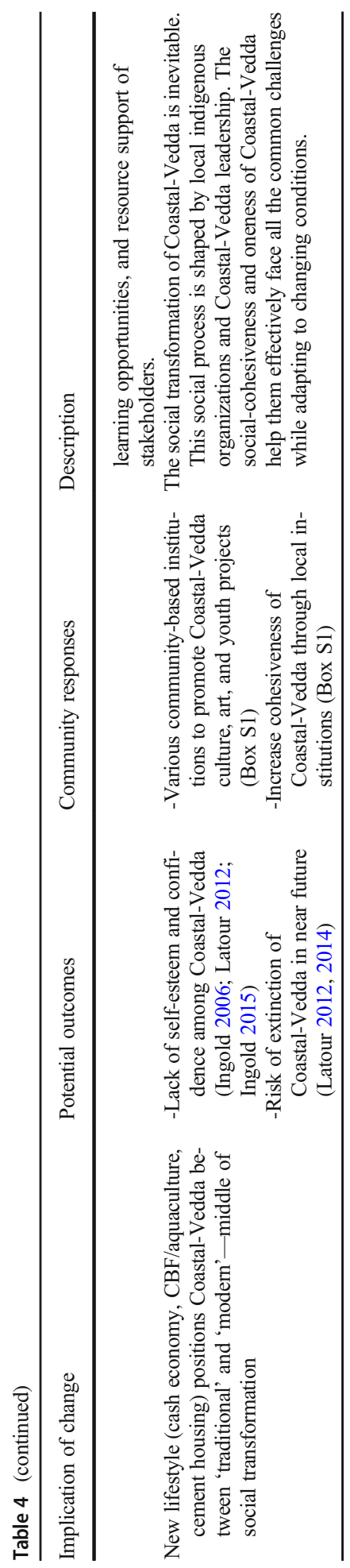


multiple funders (RFO, NGOs, government) (Chandrasoma and Pushpalatha 2018), and (iii) creates opportunities to collaborate and co-learn with external information/knowledge sources. Globally, aquaculture is identified as an adaptive strategy for climate change impacts and is included in some countries' national natural resources strategies (e.g., Solomon Islands, Vanuatu, Timor-Leste, Fiji, and Vietnam) (Bosma et al. 2012; Dey et al. 2016a, b; Rosegrant et al. 2016).

Second, adaptive institutions with a multi-level institutional structure are the heart of community adaptation. The key features of Coastal-Vedda adaptive institutions (Boyd and Folke 2012; Galappaththi et al. 2018) are (i) RFO is the key community institution for CBF, representing all Coastal-Vedda fishers; (ii) the presence of multi-level institutions (RFOcommunity, IFF - regional, NFF — national) (Galappaththi and Berkes 2014); (iii) the existence of mixed regimes of community, government, and NGOs to fund culture-based fishery systems (Galappaththi and Berkes 2015a); (iv) the bottom-up nature of functioning (feedback escalated from the community level to the national level) (Galappaththi and Berkes 2014); and (v) adaptive nature - multi-level industry association structure collaborates/links with various stakeholder organizations (NAqDA, Department of Fisheries, NGOs) based on need (e.g., connect with NAqDA for general aquaculture management, with the Department of Fisheries for canoe licensing, and with NGOs for funding community projects).

These adaptive institutions facilitate the co-management of CBF and allow Coastal-Vedda to co-learn with each other by practicing collective action and collaboration. Table S9 in the appendix highlights the characteristics of the co-management process of the Coastal-Vedda's $\mathrm{CBF}$ and the ways in which it advances adaptation. Furthermore, these local institutions create social space for the co-production of knowledge (Armitage et al. 2011) and the emergence of collective leadership (Lichtenstein and Plowman 2009; Friedrich et al. 2016) required for community adaptation. Moreover, these adaptive institution levels and institutional robustness are similar to those found in other reservoirs in Sri Lanka where there are farmer organizations (small village reservoirs under the jurisdiction of the Agrarian Development Department (Kularatne et al. 2009)) and perennial reservoirs (Kulatilake et al. 2010). The present study based on a resilience-based conceptual framework indicates the uniqueness of the Vedda communities, whose norms are based on their traditional culture, which are rapidly disappearing due to external forces.

Third, diversification is a common strategy across Coastal-Vedda responses in the aquaculture and fishery setting, livelihoods, institutions, knowledge systems, and learning opportunities. (Table S8 in the appendix explains how types of diversification advance adaptation.) For example, in broader developing context, households diversify income sources for two reasons: (a) people are too poor (finances, power, skills, innovations) to specialize and (b) people are wealthy enough to invest and expand their portfolio of income (O. T. Coomes, pers. comm.). However, Coastal-Vedda transformation in the face of livelihood distractions, social-marginalization, and disempowerment due to governmental mega development projects and civil war hints at the complexity of reasons for livelihood diversification. Also, diversification is a broad application known to be a source of system resilience and a means of adaptation in the context of climate change impacts (e.g., small-scale shrimp farmers in northwestern Sri Lanka) (Galappaththi et al. 2018). Nurturing diversity in a changing SES can increase creativity and adaptive capacity as well as set the system for reorganization and renewal (Folke et al. 2003; Folke 2016). We identified diversification as an adaptive strategy used in combination with other strategies in a Coastal-Vedda fisheries and aquaculture setting. 
In addition to the three identified community adaptive strategies, we identified four placespecific attributes that support adaptive strategies and shape community adaptation: CoastalVedda's cultural identity and worldviews (Escobar 2008), co-management of CBF (Galappaththi and Berkes 2015b), flexibility towards adaptation (Cinner et al. 2018), and ILK systems and learning (Rodríguez et al. 2019) (Appendix-Table S10). Each attribute can support adaptation under the given circumstances, e.g., Coastal-Vedda's cultural identity and flexibility in working with diverse aquaculture stakeholders help support community CBF. Combined, these four attributes will reduce systems' vulnerability and build the Coastal-Vedda fishery system's resilience by increasing adaptive capacity. Four attributes, together or in combination with identified adaptive strategies, collectively influence the community's process of adaptation to change. For instance, during the rainy season, Coastal-Vedda incur more damage from wild elephants, which can be addressed in part by a broad range of adaptive responses such as more reliance on $\mathrm{CBF}$ (for food), the use of saved money to buy food, and the earning of money from other identified livelihood activities.

\section{Conclusion}

In this paper, we examine how indigenous fishers experience and respond to environmental and social stressors, including climate change, socio-economic change, and political change, by assessing community adaptations of the rural Coastal-Vedda population in Sri Lanka. Coastal-Vedda have multiple responses that help them adapt to these stressors. Our findings highlight three adaptive strategies (adaptive multi-level institutional structure, aquaculture/ $\mathrm{CBF}$, and diversification) as well as four place-specific attributes (worldviews, co-management, flexibility, and ILK/learning) that shape community adaptation. Our study provides key insights for communities, scientists, and policymakers to improve community adaptation to increasing rates of global change: (1) Understanding how tropical indigenous fishers experience and respond to change is essential to improving adaptation; we suggest that such assessments can be carried out using the six characteristics of the resilience-based conceptual framework (place, human agency, collective action, institutions, ILK, and learning) that we developed. (2) Recognizing information required to link community adaptation realities to government plans (e.g., the National Adaptation Plan of Sri Lanka) can result in the development of a better fishery adaptation policy (e.g., multi-level institutional structure) under the comanagement of the CBF setting. (3) Understanding community adaptations can enable communities to self-evaluate their adaptation and adjust as needed. This may be particularly important for indigenous populations undergoing social transformation. Overall, the case study helps fill the empirical knowledge gap in climate change adaptation in the context of rural indigenous people and their small-scale aquaculture systems, as well as in how they respond to SES change until they find their new system equilibrium.

\section{References}

Aaronson SA (2016) Repression, civil conflict, and leadership tenure:the Sri Lanka case study, Institute for International Economic Policy Working Paper Series, Elliott School of International Affairs, the George Washington University. Washington, D.C.

Adger WN (2003) Social capital, collective action, and adaptation to climate change. Econ Geogr 79:387-404 
Adger WN (2016) Place, well-being, and fairness shape priorities for adaptation to climate change. Glob Environ Chang 38:A1-A3

Agrawal A (1995) Dismantling the divide between indigenous and scientific knowledge. Dev Chang 26(3):413439

Amarasinghe US, Nguyen TTT (2009) Enhancing rural farmer income through fish production: secondary use of water resources in Sri Lanka and elsewhere. In: De Silva SS, Davy FB (eds) Success stories in Asian aquaculture. Springer Science, Netherlands

Amarasinghe US, Wijenayake WMHK (2015) Results of a decade of R \& D efforts on culture-based fisheries in Sri Lanka. In: De Silva SS, Ingram BA, Wilkinson S (eds.) Perspectives on culture-based fisheries development in Asia. Proceedings of the Regional Consultation on Culture-Based Fisheries Developments in Asia, 21st to 23rd October 2014, Siem Reap, Cambodia. NACA, Bangkok and ACIAR, Canberra.

Amundsen H (2015) Place attachment as a driver of adaptation in coastal communities in Northern Norway. Local Environ 20:257-276

Arimi KS (2014) Determinants of climate change adaptation strategies used by fish farmers in Epe Local Government Area of Lagos State, Nigeria. J Sci Food Agric 94:1470-1476

Arlinghaus R, Alós J, Beardmore B, Daedlow K, Dorow M, Fujitani M, Hühn D, Haider W, Hunt L, Johnson B (2017) Understanding and managing freshwater recreational fisheries as complex adaptive social-ecological systems. Rev Fish Sci Aquac 25:1-41

Armitage D (2005) Adaptive capacity and community-based natural resource management. Environ Manag 35 : $703-715$

Armitage D, Berkes F, Dale A, Kocho-Schellenberg E, Patton E (2011) Co-management and the co-production of knowledge: learning to adapt in Canada's Arctic. Glob Environ Chang 21:995-1004

Attanapola CT, Lund R (2013) Contested identities of indigenous people: indigenization or integration of the Veddas in Sri Lanka. Singap J Trop Geogr 34:172-187

Béné C, Newsham A, Davies M, Ulrichs M, Godfrey-Wood R (2014) Review article: resilience, poverty and development. J Int Dev 26:598-623

Béné C et al (2015) Feeding 9 billion by 2050-putting fish back on the menu. Food Sec 7(2):261-274

Béné C et al (2016a) Is resilience socially constructed? Empirical evidence from Fiji, Ghana, Sri Lanka, and Vietnam. Glob Environ Chang 38:153-170

Béné C et al (2016b) Contribution of fisheries and aquaculture to food security and poverty reduction: assessing the current evidence. World Dev 79:177-196

Béné C et al (2016c) Is resilience a useful concept in the context of food security and nutrition programmes? Some conceptual and practical considerations. Food Sec 8(1):123-138

Berg BL (2016) Qualitative research methods for the social sciences. Pearson Education, Boston

Berkes F, Folke C, Colding J (eds) (1998) Linking social and ecological systems: management practices and social mechanisms for building resilience. Cambridge University Press, Cambridge

Berkes F, Colding J, Folke C (eds) (2003) Navigating social-ecological systems: building resilience for complexity and change. Cambridge University Press, New York

Blanchard JL et al (2017) Linked sustainability challenges and trade-offs among fisheries, aquaculture and agriculture. Nat Ecol Evol 1(9):1240

Bosma RH, Nhan DK, Udo HM, Kaymak U (2012) Factors affecting farmers' adoption of integrated rice-fish farming systems in the Mekong delta, Vietnam. Rev Aquac 4:178-190

Bowen GA (2008) Naturalistic inquiry and the saturation concept: a research note. Qual Res 8:137-152

Boyd E, Folke C (eds) (2012) Adapting institutions: governance, complexity and social-ecological resilience. Cambridge University Press, New York

Brow J (1978) Veddha villages of Anuradhapura: the anthropological history of a community in Sri Lanka. University of Washington Press, Seattle

Brown K (2016) Resilience, development and global change. Routledge, New York

Carey MA, Asbury J-E (2016) Focus group research. Routledge, London

Chandrasoma J, Pushpalatha KBC (2018) Fisheries enhancements in inland waters in Sri Lanka with special reference to culture based fisheries: current status and impacts. Sri J Aqua Sci. 23:49-65

Childs K (2017) Culture and life: the last Veddas of Sri Lanka. Guardian (Sydney) 10

Cinner JE, Huchery C, Hicks CC, Daw TM, Marshall N, Wamukota A, Allison EH (2015) Changes in adaptive capacity of Kenyan fishing communities. Nat Clim Chang 5:872-876

Cinner JE, Adger WN, Allison EH, Barnes ML, Brown K, Cohen PJ, Gelcich S, Hicks CC, Hughes TP, Lau J (2018) Building adaptive capacity to climate change in tropical coastal communities. Nat Clim Chang 8: $117-123$

Clifford N, Cope M, French S, Gillespie T (2016) Key methods in geography. Sage, London

De Jong K, Mulhern M, Ford N, Simpson I, Swan A, Van Der Kam S (2002) Psychological trauma of the civil war in Sri Lanka. Lancet 359:1517-1518 
De Silva SS, Amarasinghe US, Nguyen TT (2006) Better-practice approaches for culture-based fisheries development in Asia. ACIAR Monograph, Canberra

De Silva C, Weatherhead E, Knox JW, Rodriguez-Diaz J (2007) Predicting the impacts of climate change-a case study of paddy irrigation water requirements in Sri Lanka. Agric Water Manag 93:19-29

Dey MM, Gosh K, Valmonte-Santos R, Rosegrant MW, Chen OL (2016a) Economic impact of climate change and climate change adaptation strategies for fisheries sector in Fiji. Mar Policy 67:164-170

Dey MM, Gosh K, Valmonte-Santos R, Rosegrant MW, Chen OL (2016b) Economic impact of climate change and climate change adaptation strategies for fisheries sector in Solomon Islands: implication for food security. Mar Policy 67:171-178

Dharmadasa KNOO (1993) Vedda: the 'Adivasi' of Sri Lanka. SOBA 4:3, 7-11. Ministry of Environment and Parliamentary Affairs, Sri Lanka

Escobar A (2008) Territories of difference: place, movements, life, redes. Duke University Press, Durham and London

Esham M, Garforth C (2013) Climate change and agricultural adaptation in Sri Lanka: a review. Clim Dev 5:6676

Fernando P, Wikramanayake E, Weerakoon D, Jayasinghe L, Gunawardene M, Janaka H (2005) Perceptions and patterns of human-elephant conflict in old and new settlements in Sri Lanka: insights for mitigation and management. Biodivers Conserv 14:2465-2481

Folke C (2016) Resilience (republished). Ecol Soc 21:44

Folke C, Colding J, Berkes F (2003) Synthesis: building resilience and adaptive capacity in social-ecological systems. In: Berkes F, Colding J, Folke C (eds) Navigating social-ecological systems: building resilience for complexity and change. Cambridge University Press, New York

Friedrich TL, Griffith JA, Mumford MD (2016) Collective leadership behaviors: evaluating the leader, team network, and problem situation characteristics that influence their use. Leadersh Q 27:312-333

Galappaththi EK, Berkes F (2014) Institutions for managing common-pool resources: the case of communitybased shrimp aquaculture in northwestern Sri Lanka. Maritime Studies 13:1-16

Galappaththi E, Berkes F (2015a) Drama of the commons in small-scale shrimp aquaculture in northwestern, Sri Lanka. Int J Commons 9:347-368

Galappaththi EK, Berkes F (2015b) Can co-management emerge spontaneously? Collaborative management in Sri Lankan shrimp aquaculture. Mar Policy 60:1-8

Galappaththi E, Berkes F, Ford J (2018) Climate change adaptation efforts in coastal shrimp aquaculture: a case from northwestern Sri Lanka. In: Johnson J, De Young C, Bahri T, Soto D, Virapat C (eds) FishAdapt: The Global Conference on Climate Change Adaptation for Fisheries and Aquaculture, 2018 Bangkok. FAO Fisheries and Aquaculture Proceedings No. 61. Rome, FAO

Galappaththi EK, Ford JD, Bennett EM (2019) A framework for assessing community adaptation to climate change in a fisheries context. Environ Sci Pol 92:17-26

Gunatilaka A (2017) Water security and related issues in Sri Lanka: the need for integrated water resource management (IWRM). J Natl Sci Found 36

Hancock DR, Algozzine B (2015) Doing case study research: a practical guide for beginning researchers. Teachers College Press, London

Herath T, Joseph J (2016) Prevalence of risk factors of under-nutrition among children 1 to 5 years in eastern, Sri Lanka. J Food Nutr Sci 4:103-107

Ingold T (2015) The life of lines. Routledge, New York

Ingold T (2006) Rethinking the animate, re-animating thought. Ethnos 71(1):9-20

Islam MM et al (2014) Vulnerability of fishery-based livelihoods to the impacts of climate variability and change: insights from coastal Bangladesh. Reg Environ Chang 14(1):281-294

Kaján E (2014) Community perceptions to place attachment and tourism development in Finnish Lapland. Tour Geogr 16:490-511

Khan FN, Collins AM, Nayak PK, Armitage D (2018) Women's perspectives of small-scale fisheries and environmental change in Chilika lagoon, India. Maritime Studies 17:145-154

Krippendorff K (2018) Content analysis: an introduction to its methodology. Sage publications, London

Kularatne MG, Amarasinghe US, Wattage P, De Silva SS (2009) Evaluation of community participation for the development of culture-based fisheries in village reservoirs of Sri Lanka. Aquac Econ Manag 13:22-38

Kulatilake M, Liyanage HSWA, Fernando WMJR, Chandrasoma J, Der Knapp MV (2010) Development of comanagement in inland fisheries in Sri Lanka: case studies of Senanayake Samudra and Mahavilachchiya reservoirs. Aquat Ecosyst Health Manag 13:281-287

Latour B (2012) We have never been modern. Harvard University Press, Cambridge

Latour B (2014) Agency at the time of the anthropocene. New Lit Hist 45(1):1-18

Laurier E (2016) Participant and non-participant observation. In: Clifford N, Cope M, French S, Gillespie T (eds) Key methods in geography. Sage, London 
Lehman J (2014) Expecting the sea: the nature of uncertainty on Sri Lanka's east coast. Geoforum 52:245-256

Lichtenstein BB, Plowman DA (2009) The leadership of emergence: a complex systems leadership theory of emergence at successive organizational levels. Leadersh Q 20:617-630

Lobe K, Berkes F (2004) The padu system of community-based fisheries management: change and local institutional innovation in south India. Mar Policy 28:271-281

Longhurst R (2016) Semi-structured interviews and focus group. In: Clifford N, Cope M, Gillespie T, FRENCH $\mathrm{S}$ (eds) Key methods in geography, 3rd edn. Sage, London

Lund R (2000) Geographies of eviction, expulsion and marginalization: stories and coping capacities of the Veddhas, Sri Lanka. Nor Geogr Tidsskr 54:102-109

Magee T (2013) A field guide to community based adaptation. Routledge, London

Mahon R, Mcconney P, Roy RN (2008) Governing fisheries as complex adaptive systems. Mar Policy 32:104 112

Paprocki K, Cons J (2014) Life in a shrimp zone: aqua-and other cultures of Bangladesh's coastal landscape. J Peasant Stud 41:1109-1130

Pelling M, High C, Dearing J, Smith D (2008) Shadow spaces for social learning: a relational understanding of adaptive capacity to climate change within organisations. Environ Plan A 40:867-884

Pelling M, O’Brien K, Matyas D (2015) Adaptation and transformation. Clim Chang 133:113-127

Pushpalatha KBC, Chandrasoma J (2010) Culture-based fisheries in minor perennial reservoirs in Sri Lanka: variability in production, stocked species and yield implication. J Appl Ichthyol 26:98-103

Ranasinghe R, Cheng L (2018) Tourism-induced mobilities and transformation of indigenous cultures: where is the Vedda community in Sri Lanka heading to? J Tour Cult Chang 16:521-538

Rodríguez MV, Davidson-Hunt I, Berkes F (2019) Social-ecological memory and responses to biodiversity change in a Bribri Community of Costa Rica. Ambio Biodivers Change Hum Adapt:1-12

Rosegrant MW, Dey MM, Valmonte-Santos R, Chen OL (2016) Economic impacts of climate change and climate change adaptation strategies in Vanuatu and Timor-Leste. Mar Policy 67:179-188

Santiapillai C, Wijeyamohan S, Bandara G, Athurupana R, Dissanayake N, Read B (2010) An assessment of the human-elephant conflict in Sri Lanka. Ceylon J Sci (Bio Sci) 39

Seligmann CG, Seligmann B (eds) (1911) The veddas. Cambridge University Press, Cambridge

Singh SJ (2009) Complex disasters: The nicobar islands in the grip of humanitarian aiod. Geographische Rundschau International Edition 5(3):48-56

Truelove HB, Carrico AR, Thabrew L (2015) A socio-psychological model for analyzing climate change adaptation: a case study of Sri Lankan paddy farmers. Glob Environ Chang 31:85-97

Vaismoradi M, Jones J, Turunen H, Snelgrove S (2016) Theme development in qualitative content analysis and thematic analysis. J Nurs Educ Pract 6:100-110

Van Dijk TA (2015) Critical discourse analysis. In: Tannen D, Hamilton HE, Schiffrin D (eds) The handbook of discourse analysis. Wiley, New Delhi

Wijenayake WHHK, Amarasighe US, De Silva SS (2016) Application of a multiple-criteria decision making approach for selecting non-perennial reservoirs for culture-based fishery development: case study from Sri Lanka. Aquaculture 459:26-35

Williams DR, Patterson ME (2008) Place, leisure, and well-being. In: Eyles J, Williams A (eds) Sense of place, health and quality of life. Ashgate, Surrey

Wodak R, Meyer M (2015) Methods of critical discourse studies. Sage, London

Yamada S, Gunatilake RP, Roytman TM, Gunatilake S, Fernando T, Fernando L (2006) The Sri Lanka tsunami experience. Disaster Manag Response 4:38-48

Yamane A (2003) Rethinking vulnerability to climate change in Sri Lanka. 9th International conference on Sri Lanka Studies, 28th-30th November

Yow VR (2014) Recording oral history: a guide for the humanities and social sciences. Rowman \& Littlefield, New York

Zoysa SR (2018) Fishing, Mobility and Settlerhood, Coastal Socialites in Postwar Sri Lanka, MARE Publication Series 20, Springer international Publishing AG, part of Springer Nature

Publisher's note Springer Nature remains neutral with regard to jurisdictional claims in published maps and institutional affiliations. 